\title{
Tyrosinase Enzymes Activities and Sun Protection Factor of Ethanol Extract, Water Fraction, and n-Butanol Fraction of Chromolaena odorata L. Leaves
}

Karlina Amir Tahir ${ }^{1,2 *} \mathbb{D}$, Upik A. Miskad ${ }^{3}$, Khairuddin Djawad $^{4}$ D , Sartini Sartini ${ }^{5}$, M. Natsir Djide ${ }^{6}$ (D), Maulita Indrisari ${ }^{2}$, Khaerani Khaerani ${ }^{1} \mathbb{D}$, Syamsuri Syakri ${ }^{1}$, Anshari Masri ${ }^{7}$, Ahmad Lalo ${ }^{8} \mathbb{D}$

${ }^{1}$ Department of Pharmacy, Faculty of Medicine and Health Science, Alauddin State Islamic University, Makassar, Indonesia; ${ }^{2}$ Postgraduate Doctoral Program, Faculty of Medicine, Universitas Hasanuddin, Makassar, Indonesia; ${ }^{3}$ Department of Anatomical Pathology, Faculty of Medicine, Universitas Hasanuddin, Makassar, Indonesia; ${ }^{4}$ Department of Dermatology and Gender, Faculty of Medicine, Universitas Hasanuddin, Makassar, Indonesia; ${ }^{5}$ Department of Pharmacy and Science, Faculty of Pharmacy, Universitas Hasanuddin, Makassar, Indonesia; ${ }^{6}$ Department of Microbiology, Sekolah Tinggi IImu Farmasi Makassar, Makassar, Indonesia; ${ }^{7}$ Department of Pharmacy, Faculty of Medicine and Health Science, Universitas Muhammadiyah Makassar, Makassar, Indonesia; ${ }^{8}$ National Agency of Drug and Food Control, Makassar, Indonesia

Abstract

Edited by: Sinisa Stojanos Citation: Tahir KA, Miskad UA, Djawad K, Sartin Djide MN, Indrisari M, Khaerani, Syakri S, Masri A. Thyrosinase Enzymes Activities and Sun Protection Facto of Ethanol Extract, Water Fraction, and n-Butanol Fractio of Chromolaena Odorata L. Leaves. Open Access Mace . Med Sci. 2021 Aug 08, 9(A):493-498. Keywords: Chromolaena odorata L.; Tyrosinase enzyme; Sun protection factor
${ }^{*}$ Correspondence: Karlina Amir Tahir, Department of Pharmacy, Faculty of Medicine and Health Science, Alauddin State Islamic University, Makassar, Indonesia. E-mail: karlina.amir@uin-alauddin.ac.id Received: $17-\mathrm{Apr}-202$ Revised: 17-May-2021 Copyright: $\odot 2021$ Karlina Amir Tahir, Upik A. Miskad Khairuddin DJawad, Sartini, M. Natsi Djde, Mauli ding: This research was supported by 5000 Doctora Scholarship Program in 2018 Competing Interests: The authors have declared that no Open Access: This is an open-access article distributed under the terms of the Creative Commons AttributionNonCommercial 4.0 International License (CC BY-NC 4.0)

\section{Introduction}

Tyrosinase is an oxidase enzyme that contains copper and can be found in animals, plants, and microorganisms. Besides, Tyrosinase is a key enzyme that can catalyze the enzyme browning and melanin synthesis. Tyrosinase also exhibits monophenolase and diphenolase activity. It catalyzes L-tyrosine hydroxylation to L-3,4-dihydroxyphenylalanin (L-DOPA) and L-DOPA oxidation dopaquinone, which can undergo non-enzymatic polymerization to produce dark pigments [1], [2].

In humans, excess tyrosinase causes excess melanin production in the skin, which can lead to hyperpigmentation effects such as the appearance of freckles, melismas, age spots, and melanoma. The increase in the number or activity of free radicals in the living system can trigger an increase in melanin production [3], [4].

UV rays come from sunlight. UV rays (ultraviolet) consisting of UV-A (320-400 nm), UV-B (290-320 nm), and UV-C (200-290 nm). Sunlight that reaches the surface of the earth and impacts the skin is UV-A and UV-B rays. UV rays are needed by the skin in skin rejuvenation and other skin health to a certain extent. However, excessive amounts of UV radiation can cause skin problems. Excessive UV radiation exposure is a trigger factor in skin problems such as cracked skin, burns, immune suppression, wrinkles, dermatitis, urticaria, aging, hypopigmentation, hyperpigmentation, and complications of skin cancer [5], [6].

Human skin is constantly exposed to ultraviolet radiation (UVR), an induction factor for reactive oxygen 
species (ROS). Excessive ROS levels can cause skin pigmentation or even direct DNA damage and cause injury to the skin. The antioxidant defense system helps improve oxidative stress [7].

Skin pigmentation is another mechanism for preventing UVR damage. Melanin absorbs UVR, thus protecting skin cells from UVR damage. Therefore, normal skin pigmentation is significant for human health. Tyrosinase plays a role in catalyzing skin pigmentation and is directly related to pigmentation disorders in mammals. It is a prime target for discovering and screening new inhibitors because of its central role in melanogenesis [8].

There is an exciting and subtle relationship between the defense system by antioxidants and melanogenesis. This relationship is related to ROS entrapment. The synergistic effect, in this case, is the increased effectiveness of antioxidants in absorbing free radicals when tyrosinase inhibitors work, thereby reducing melanin production. Protection of the skin from the tyrosinase enzyme's excess activity and UV radiation is vital for maintaining healthy skin [9].

The development of plant-based antioxidants is at the center of attention today. Of the various plants that are being developed, one of them is Chromolaena odorata L. leaves. Its leaves have an antioxidant profile, as shown by several previous studies. In this research, the benefits of $C$. odorata leaves will be developed as an antioxidant by measuring their ability to inhibit the tyrosinase enzyme and inhibit UV radiation by determining the SPF value.

\section{Methods}

\section{Materials}

All materials and reagents used in this study were pro-analytic (p.a) specifications and obtained from Sigma-Aldrich (St. Louis, USA). Tyrosinase enzyme from mushrooms in lyophilized powder was obtained from Sigma Chemical Co. (St. Louis, USA).

\section{Sample preparation}

\section{Extraction and fractionation}

The leaves of Chromolaena odorata L. obtained from Takalar District, South Sulawesi, are cleaned, dried, and pollinated. The powder was immersed in $70 \%$ ethanol solvent and sonicated using a sonicator (Elma $\left.{ }^{\circledR}\right)$ for 15 min. Extraction was carried out with $70 \%$ ethanol solvent three times until the filtrate became clear. The concentrated filtrate was evaporated at a rotary evaporator and dried using desiccator. The extract was then fractionated with different solvents, which are n-hexane, water, and n-butanol (water-saturated), using the liquid-liquid extraction (LLE) method, respectively. All the fractions were then dried using a freeze dryer Lyophilizer by brand Büchi L200, Germany.

\section{Phytochemical screening of Chromolaena} odorata L. leaf extract fraction

Screening using the TLC method with $10 \% \mathrm{AICl}_{3}$ spray reagent for identification of flavonoid compounds and $10 \% \mathrm{FeCl}_{3}$ for identification of phenolic compounds. The eluent used was ethyl acetate: methanol with a ratio of 5: 1. The spots were observed using UV $254 \mathrm{~nm}$ and $366 \mathrm{~nm}$.

\section{Quantitative test of chemical content of} Botto-Botto (Chromolaena odorata L.) leaf extract fraction

Total flavonoid levels were tested using quercetin standards and total polyphenol levels using gallic acid standards.

\section{Tyrosinase enzyme inhibitory activity analysis}

Preparation of phosphate buffer solution

A total of $2.7 \mathrm{~g} \mathrm{KH}_{2} \mathrm{PO}_{4}$ was dissolved in distilled water gradually until a volume of $400 \mathrm{~mL}$ was sufficient. Then the $\mathrm{pH}$ of the solution was measured using a $\mathrm{pH}$ meter. A total of $5,6 \mathrm{~g} \mathrm{KOH}$ was dissolved it in $100 \mathrm{~mL}$ of distilled water. The $\mathrm{KOH}$ solution was added to the $\mathrm{KH}_{2} \mathrm{PO}_{4}$ solution until it reached a $\mathrm{pH}$ of 6.8. The phosphate buffer solution was stored in the refrigerator.

\section{Preparation of L-tyrosine solution}

A total of $18.2 \mathrm{mg}$ of L-tyrosine was put into a $100 \mathrm{~mL}$ volumetric flask, added to the phosphate buffer gradually, and homogenized. The volume was sufficient to $100 \mathrm{~mL}$ with a phosphate buffer solution.

Preparation of the tyrosinase enzyme solution

A total of $1 \mathrm{mg}$ of tyrosinase enzyme was put into a $10 \mathrm{~mL}$ measuring flask dissolved in $10 \mathrm{~mL}$ of cooled phosphate buffer solution. The tyrosinase enzyme solution was placed in a container filled with ice to keep the enzyme temperature stable at cold temperatures during processing

\section{Preparation of leaf extract test solution}

Preparation of kojic acid as a positive control solution

A total of $5 \mathrm{mg}$ kojic acid was put into an ependorphous tube and dissolved in $5 \mathrm{ml}$ of $50 \mathrm{mM}$ 
phosphate buffer solution $(\mathrm{pH}, 6.5)$. The kojic acid solution was then diluted to obtain a kojic acid solution with the same concentration as the test solution.

\section{Determination of the inhibitory activity of the tyrosinase enzyme}

A total of $50 \mu \mathrm{l}$ of $1 \mathrm{mM}$ L-Tyrosine, $50 \mu \mathrm{l}$ of $50 \mathrm{mM}$ of phosphate buffer solution ( $\mathrm{pH} \mathrm{6.8),} 20 \mu$ of tyrosinase enzyme solution, and $100 \mu \mathrm{l}$ of sample solution were put into the well on the microplate. The mixture was incubated for $5 \mathrm{~min}$ at room temperature. Then the absorption was measured using a microplate reader (ELISA) at a wavelength of $490 \mathrm{~nm}$. A blank test was carried out without the addition of enzymes, namely, $170 \mu \mathrm{l}$ of phosphate buffer solution $(\mathrm{pH} \mathrm{6.8)}$, $50 \mu \mathrm{l}$ L-Tyrosine $1 \mathrm{mM}$ were used. The negative control used the above mixture without additional samples. The positive control used kojic acid as a sample substitute. The steps mentioned above are carried out in triplo.

The determination of the percentage inhibition of tyrosinase activity is based on the formula:

$\%$ Tyrosinase inhibition $=\mathrm{A}-\mathrm{BA} \times 100 \%$

Note:

$A=$ Absorbance of the sample without inhibitor.

$B=$ Absorbance of the sample with inhibitor.

The test sample's inhibitory activity was determined by $\mathrm{IC}_{50}$, namely the concentration at which the test sample inhibited tyrosinase activity by $50 \%$. $\mathrm{IC}_{50}$ was calculated using a linear regression equation. The log sample concentration as the $\mathrm{X}$-axis and the $\%$ inhibition probit as the $\mathrm{Y}$-axis, from the equation $y=b x \pm a$, and the $I_{50}$ value could be calculated.

Formula: $I_{50} y=a x+b, x=(50-a): b$

Note:

$$
\mathrm{a}=\text { slope }
$$

$\mathrm{b}=$ intercept

$\mathrm{IC}_{50}$ values below $100 \mu \mathrm{g} / \mathrm{mL}$ indicated the strong inhibitory potential of tyrosinase activity, 100$450 \mu \mathrm{g} / \mathrm{mL}$ indicated weak tyrosinase activity inhibitory potential, and $450-700 \mu \mathrm{g} / \mathrm{mL}$ indicated very weak potential inhibition of tyrosinase activity.

\section{Determination of SPF value}

SPF value in vitro using spectrophotometric method [10], we weighed the sample, and then made several variants of the concentration $(\mu \mathrm{g} / \mathrm{mL})$ by diluting the sample with $70 \%$ to $10 \mathrm{ml}$ ethanol. The UV-Vis spectrophotometer was calibrated first using $70 \%$ ethanol and $1 \mathrm{ml}$ of $70 \%$ ethanol inserted into the cuvette. A test absorption curve was made in a cuvette with a wavelength between 290 and $320 \mathrm{~nm}$, $70 \%$ ethanol was used as a blank and then determined the average absorption (Ar) at $5 \mathrm{~nm}$ intervals. The absorbance results of each cream concentration were recorded, and then the SPF value was calculated, carried out three times. The SPF value was analyzed using the Mansur method

$$
\operatorname{SPF}=\mathrm{CF} \times \sum_{290}^{320} \mathrm{EE}(\lambda) \times \mathrm{I}(\lambda) \times \operatorname{Abs}(\lambda)
$$

Note:

EE: Erythemal effect spectrum

I: Solar intensity spectrum

Abs: Absorbance of sunscreen product

CF: Correction factor $(=10)$.

\section{Results and Discussion}

Table 1 shows that the results of the Chromolaena odorata leaf extract are Simplicia weight of $800 \mathrm{~g}$, Extract Weight of $181 \mathrm{gr}$, and Rendement of 22.625 .

Table 1: The results of the extraction of $C$. odorata leaves

\begin{tabular}{lll}
\hline Simplicia weight (g) & Extract Weight (g) & Rendement (\%) \\
\hline 800 & 181 & 22.625 \\
\hline
\end{tabular}

Table 2 shows that the highest value of total polyphenols and total flavonoids is in the n-butanol fraction.

Table 2: Test results for total polyphenols and total flavonoids

\begin{tabular}{lll}
\hline Sample & Total polyphenol value (\%) & Total flavonoid value (\%) \\
\hline Ethanol extract & 10.56 & 2.70 \\
n-butanol fraction & 18.08 & 7.06 \\
n-hexane fraction & 14.30 & 0.92 \\
Water fraction & 11.87 & 1.00 \\
\hline
\end{tabular}

Identification of $C$. odorata leaves contained Phenolic and Flavonoids in three samples which were checked with positive results (Table 3 ).

Table 3: Identification results of the $C$. odorata leaf fraction compound components

\begin{tabular}{llll}
\hline Compound & Sample & & \\
\cline { 2 - 4 } & Water fraction & n-butanol fraction & n-hexane fraction \\
\hline Phenolic & + & + & + \\
Flavonoids & + & + & + \\
\hline Present (+), Absent (-) & & &
\end{tabular}

This study has resulted in two categories, tyrosinase enzyme activity in $\mathrm{IC}_{50}$ value and SPF value of ethanol extract, n-butanol fraction, and water fraction of $C$. odorata and kojic acid, a comparison standard. Testing tyrosinase enzyme inhibition on the leaf samples was carried out using a microplate reader (ELISA). This study used the tyrosinase enzyme synthesized from fungi and L-tyrosine as the substrate. The maximum activity of the tyrosinase enzyme was at $\mathrm{pH}$ 6.8. Hence, it was buffered with a phosphate buffer 
of $\mathrm{pH} 6.8$ that had been cooled. The tyrosinase enzyme was also stable at $-20^{\circ} \mathrm{C}$, so storing and processing it must remain in a cold container.

Testing the tyrosinase enzyme's inhibitory activity was based on the enzyme's ability to catalyze L-Tyrosine's oxidation as a substrate to L-DOPA [11]. A further oxidation process occurred in the tyrosinase enzyme's presence with a catalyst that converts L-DOPA into DOPAquinone. Furthermore, DOPAquinone would spontaneously automerize to become DOPAchrome. The final result in the form of DOPAchrome would give a purple color that absorbed visible light energy at a wavelength of $490 \mathrm{~nm}$. Analyzing the tyrosinase enzyme inhibition activity by ethanol extract, n-butanol fraction, and water fraction from Chromolaena odorata L. leaves was carried out using L-tyrosine as substrate, and kojic acid as a positive control. Kojic acid was chosen because it was a tyrosinase inhibitor with the highest inhibition and stability in a skin-lightening cosmetic [4], [12].

The results of the tyrosinase enzyme inhibitory activity test are shown in Table 4 . The comparison graph in Figure 1 shows that Kojic acid was used as a positive control.

Table 4: $I_{50}$ Value of $C$. odorata Leaf

\begin{tabular}{llll}
\hline Sample & Concentration $(\mu \mathrm{g} / \mathrm{mL})$ & Percent inhibition $(\%)$ & Value $\mathrm{IC}_{50}(\mu \mathrm{g} / \mathrm{mL})$ \\
\hline Ethanol extract & 10 & 24.5 & 191 \\
& 15 & 30 & \\
& 20 & 29.5 & \\
n-Butanol fraction & 25 & 25.5 & 14.59 \\
& 10 & 24 & \\
& 15 & 24.9 & \\
Water Faction & 20 & 28.2 & \\
& 25 & 27.7 & \\
& 30 & 27.2 & \\
& 10 & 5.7 & \\
Kojic acid & 15 & 23.7 & \\
& 20 & 22.6 & \\
& 25 & 20.2 & \\
& 30 & 7.5 & \\
& 10 & 22.3 & \\
& 15 & 21.9 & \\
& 20 & 21.7 & \\
& 25 & 18.7 & \\
& 30 & 9.4 & \\
\hline
\end{tabular}

The test results were carried out on ethanol extract, n-butanol fraction, and water fraction with five concentration levels, $10,15,20,25$, and $30 \mu \mathrm{g} / \mathrm{mL}$, and carried out in a triplo. The results were then compared with kojic acid made with the same concentration and calculated triplo for each concentration.

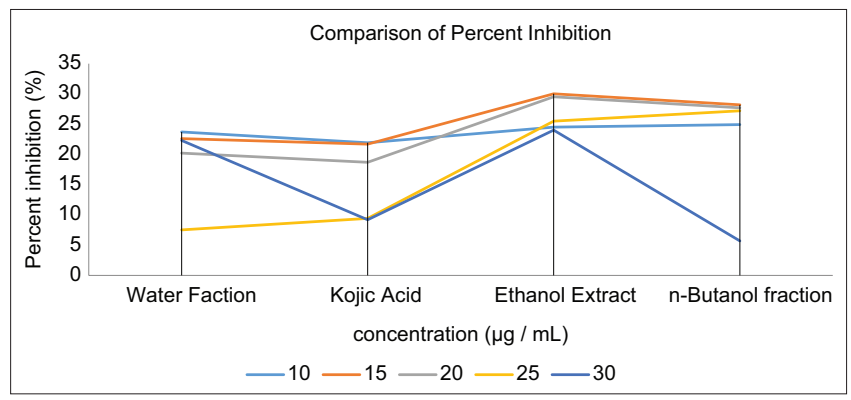

Figure 1: Comparison diagram of botto-botto leaf sample inhibition percentage
The results of the $I C_{50}$ value from the tyrosinase enzyme inhibitory activity test showed a concentration value that could inhibit $50 \%$ of the tyrosinase enzyme activity $\left(\mathrm{IC}_{50}\right)$, the kojic acid was $24.85 \mu \mathrm{g} / \mathrm{mL}$. Simultaneously, ethanol extract samples, $\mathrm{n}$-butanol fraction, and water fraction were $191 \mu \mathrm{g} / \mathrm{mL}$, $14.59 \mu \mathrm{g} / \mathrm{mL}$, and $65.86 \mu \mathrm{g} / \mathrm{mL}$, respectively (Table 4). The $I_{50}$ values for inhibition of tyrosinase activity categorized as $>100 \mu \mathrm{g} / \mathrm{mL}$ indicated the strong potential, $100-450 \mu \mathrm{g} / \mathrm{mL}$ indicated weak potential, and $450-700 \mu \mathrm{g} / \mathrm{mL}$ indicated the very weak inhibitory potential of tyrosinase activity [13]. The smaller the $I_{50}$ value, the greater the Tyrosinase inhibitory activity. The ethanol extract was categorized as weak. The water fraction and n-butanol fraction were the strong categories in tyrosinase enzyme inhibition. The $\mathrm{IC}_{50}$ value of the $\mathrm{n}$-butanol fraction was smaller than the standard kojic acid as a positive control. These results concluded that the ethanol extract, water fraction, and n-butanol fraction of $C$. odorata leaves have an inhibitory effect on Tyrosinase. Other studies have shown good anti-tyrosinase abilities at $\left.\mathrm{IC}_{50} 66.28 \mu \mathrm{g} / \mathrm{mL}\right)$ [14]. Another study demonstrated the many biological effects of the potential tyrosinase inhibitor of structurally related flavonoids (1-9) and found that all tested materials had a tyrosinase inhibitory effect compared to the positive control, and kojic acid showed the strong tyrosinase inhibitory effect with an IC value of $40.94 \pm 0.78 \mu \mathrm{M}$ [15].

The subsequent measurement was to determine the SPF value. Sun Protection Factor (SPF) is a universal indicator that explains a product's effectiveness as UV protective. The higher the SPF value of a product or active sunscreen, the more effective it is to protect the skin from UV rays' destructive effects [16].

The results of the SPF measurement are shown in Table 5 . In this study, the water fraction showed the SPF value at a $120 \mu \mathrm{g} / \mathrm{mL}$ concentration, the n-butanol fraction at $40 \mu \mathrm{g} / \mathrm{mL}$, and the ethanol extract at $60 \mu \mathrm{g} / \mathrm{mL}$. At this concentration, the SPF value was more than 2 , where this value falls within the minimum range (if the SPF range was between 2 and 4). A concentration of fewer than $120 \mu \mathrm{g} / \mathrm{mL}$ for the water fraction, $<40 \mu \mathrm{g} / \mathrm{mL}$ for the $\mathrm{n}$-butanol fraction, and $<60 \mu \mathrm{g} / \mathrm{mL}$ for ethanol extract has an SPF value of $<2$. Hence, it could not protect both UV A and UV B rays. At higher concentrations, there was a better protection value (the protection value is higher and still within a range), but further research is still needed to prove the effectiveness and benefits of better protection from this sample. Other studies show that at a concentration of $1 \%$ and $2 \%$ has a moderate SPF category with SPF values of 17.762 and 28.643. Concentrations of $3 \%$ and $4 \%$ have a high SPF category with SPF values of 30.592 and 31.325. The higher the concentration used, the better the SPF value [17]. Another study revealed that the 
Table 5: SPF Value on C. odorata Leaf

\begin{tabular}{|c|c|c|c|}
\hline No & Sample $(\mu \mathrm{g} / \mathrm{mL})$ & SPF Value & Category \\
\hline \multirow[t]{5}{*}{1} & Ethanol extract 20 & 1.24 & \\
\hline & Ethanol extract 40 & 1.61 & \\
\hline & Ethanol extract 60 & 2.02 & Minimal protection \\
\hline & Ethanol extract 80 & 2.59 & Minimal protection \\
\hline & Ethanol extract 100 & 3.57 & Minimal protection \\
\hline \multirow[t]{5}{*}{2} & n-Butanol fraction 10 & 1.28 & \\
\hline & n-Butanol fraction 20 & 1.56 & \\
\hline & n-Butanol fraction 30 & 1.90 & \\
\hline & n-Butanol fraction 40 & 2.39 & Minimal protection \\
\hline & n-Butanol fraction 50 & 2.99 & Minimal protection \\
\hline \multirow[t]{5}{*}{3} & Water faction 40 & 1.24 & \\
\hline & Water faction 80 & 1.64 & \\
\hline & Water faction 120 & 2.20 & Minimal protection \\
\hline & Water faction 60 & 2.86 & Minimal protection \\
\hline & Water faction 200 & 3.69 & Minimal protection \\
\hline
\end{tabular}

Asteraceae family's leaf extract showed SPF values ranging from 4.71 to 5.29 . Its ability to effectively block UV B was $75 \%-83 \%$. Thus, the extract is an excellent candidate for medicinal in sunscreen preparations [18].

\section{Conclusion}

The ethanol extract, water fraction, and n-butanol fraction of the Chromolaena odorata L. leaves had an inhibitory effect on the tyrosinase enzyme and had sun protection capacity to be used as an ingredient in cosmetic preparations. Novelty research, namely, the results of this research are used as the basis for further research development to be used as antiaging material.

\section{Acknowledgment}

The authors thank to the 5000 Doctoral Scholarship Program in 2018, the Ministry of Religion of the Republic of Indonesia gave the author confidence to receive doctoral-level education scholarships.

\section{References}

1. Ramsden CA, Riley PA. Tyrosinase: The four oxidation states of the active site and their relevance to enzymatic activation, oxidation and inactivation. Bioorg Med Chem. 2014;22(8):238895. https://doi.org/10.1016/j.bmc.2014.02.048

PMid:24656803

2. Zolghadri S, Bahrami A, Khan MT, Munoz-Munoz J, Garcia-Molina F, Garcia-Canovas F, et al. A comprehensive review on tyrosinase inhibitors. J Enzyme Inhib Med Chem. 2019;34(1):279-309.

PMid:30734608
3. Fu C, Chen J, Lu J, Yi L, Tong X, Kang L et al. Roles of inflammation factors in melanogenesis. Mol Med Report. 2020;21(3):1421-30.

\section{PMid:32016458}

4. Fuloria S, Subramaniyan V, Karupiah S, Kumari U, Sathasivam K, Meenakshi DU, et al. A Comprehensive review on source, types, effects, nanotechnology, detection, and therapeutic management of reactive carbonyl species associated with various chronic diseases. Antioxidants. 2020;9(11):1075. https:// doi.org/10.3390/antiox9111075

PMid:33147856

5. Donglikar M, Deore S, Deore S, Deore S. Sunscreens: A review. Pharmacogn J. 2016;8(3):171-9. https://doi.org/10.5530/ pj.2016.3.1

6. Slominski AT, Zmijewski MA, Plonka PM, Szaflarski JP, Paus R. How UV light touches the brain and endocrine system through skin, and why. Endocrinology. 2018;159(5):1992-2007. https:// doi.org/10.1210/en.2017-03230

PMid:29546369

7. Yuslianti ER. Pengantar Radikal Bebas dan Antioksidan. Ngaglik: Deepublish; 2018.

8. Del Bino S, Duval C, Bernerd F. Clinical and biological characterization of skin pigmentation diversity and its consequences on UV impact. Int J Mol Sci. 2018;19(9):2668. https://doi.org/10.3390/ijms19092668

PMid:30205563

9. Wang $Y$, Hao MM, Sun Y, Wang LF, Wang H, Zhang YJ, et al. Synergistic promotion on tyrosinase inhibition by antioxidants. Molecules. 2018;23(1):106.

PMid:29300356

10. Yulianti E, Adelsa A, Putri A. Penentuan Nilai SPF (Sun Protection Factor) Ekstrak Etanol 70 \% Temu Mangga (Curcuma mangga) dan Krim Ekstrak Etanol 70 \% Temu Mangga (Curcuma mangga) secara in Vitro Menggunakan Metode Spektrofotometri. Majalah Kesehatan FKUB. 2016;2(1):41-50. https://doi.org/10.31957/ jbp.127

11. Subramaniyan V. Hemidesmus indicus and usage for arthritic conditions. In: Bioactive Food as Dietary Interventions for Arthritis and Related Inflammatory Diseases. Amsterdam, Netherlands: Elsevier; 2019. p. 507-21. https://doi.org/10.1016/ b978-0-12-813820-5.00029-5

12. Miyazawa M, Tamura N. Inhibitory compound of tyrosinase activity from the sprout of Polygonum hydropiper L. (Benitade). Biol Pharm Bull. 2007;30(3):595-7. https://doi.org/10.1248/ bpb.30.595

PMid:17329865

13. Batubara I, Darusman LK, Mitsunaga T, Rahminiwati $M$, Djauhari E. Potency of Indonesian medicinal plants as tyrosinase inhibitor and antioxidant agent. J Biol Sci. 2010;10(2):138-44. https://doi.org/10.3923/jbs.2010.138.144

14. Ekennia A, Uduagwu D, Olowu O, Nwanji O, Oje O, Daniel B, et al. Biosynthesis of zinc oxide nanoparticles using leaf extracts of Alchornea laxiflora and its tyrosinase inhibition and catalytic studies. Micron. 2021;141:102964. https://doi.org/10.1016/j. micron.2020.102964

PMid:33232905

15. Şöhretoğlu D, Sari S, Barut B, Özel A. Tyrosinase inhibition by some flavonoids: Inhibitory activity, mechanism by in vitro and in silico studies. Bioorg Chem. 2018;81:168-74. https://doi. org/10.1016/j.bioorg.2018.08.020

16. Ou-Yang H, Jiang LI, Meyer K, Wang SQ, Farberg AS, Rige DS. Sun protection by beach umbrella vs sunscreen with a high sun protection factor: A randomized clinical trial. JAMA Dermatol. 2017;153(3):304-8. https://doi.org/10.1001/ jamadermatol.2016.4922 


\section{PMid:28114650}

17. Suhaenah A, Tahir M, Nasra N. Penentuan nilai SPF (sun protecting factor) ekstrak etanol jamur kancing (Agaricus bisporus) secara in vitro dengan metode spektrofotometri uv-vis. As Syifaa J Farm. 2019;11(1):82-7. https://doi.org/10.33096/jifa.

\section{v11i1.523}

18. Das M, Mondal S, Banerjee S, Bandyopadhyay A. In vitro sun protection factor determination from dried leaves of Elephantopus scaber L. Using ethanolic extract. Indian J Life Sci. 2017;6(1):43. 